\title{
Poor correlation between phytoplankton community growth rates and nutrient concentration in the sea
}

\author{
A. Regaudie-de-Gioux ${ }^{1,}{ }^{*}$, S. Sal ${ }^{1}$, and Á. López-Urrutia ${ }^{1}$ \\ ${ }^{1}$ Instituto Oceanografico Español, Avenida Principe de Asturias 70bis, 33212 Gijón, Spain \\ *Present address: Centro de Biologia Marinha, Rodovia Manoel Hypolito do Rego km 131.5, Praia do Cabelo Gordo, \\ São Sebastiao, 11600-000, Brazil \\ Correspondence to: A. Regaudie-de-Gioux (auroreregaudie@yahoo.fr)
}

Received: 29 August 2014 - Published in Biogeosciences Discuss.: 22 October 2014

Revised: 30 January 2015 - Accepted: 2 March 2015 - Published: 24 March 2015

\begin{abstract}
Nutrient availability is one of the major factors regulating marine productivity and phytoplankton community structure. While the response of phytoplankton species to nutrient variation is relatively well known, that of phytoplankton community remains unclear. We question whether phytoplankton community growth rates respond to nutrient concentration in a similar manner to phytoplankton species composing the community, that is, following Monod's model. Data on in situ marine community growth rates in relation to nutrient concentration and the behaviour of a simple multi-species community model suggest that community growth rate does not respond to nutrient concentration according to the Monod equation. Through a simulation study we show this can be explained as a consequence of changes in size structure. Marine biogeochemical models must not parameterize phytoplankton community growth rate response to nutrient concentration using a single Monod equation but rather involve different phytoplankton functional groups each with different equation parameters.
\end{abstract}

\section{Introduction}

There is little doubt that nutrient availability is one of the major factors regulating marine productivity and phytoplankton community structure. In most areas of the oceans, phytoplankton species compete for available nutrients. We know from laboratory experiments that most of the steady state growth rates of monocultures of phytoplankton species in a gradient of nutrient concentration are well represented by Monod theory (Dugdale, 1967). Small phytoplankton species have low half-saturation constants and high maximum growth rates that allow them to uptake nutrients at a faster rate than larger cells and to dominate in nutrient limited conditions (Eppley et al., 1969; Aksnes and Egge, 1991; Hein et al., 1995). Large phytoplankton species achieve slower growth rates (Grover, 1989) but often dominate when nutrient concentration is high (Tremblay and Legendre, 1994; Li, 2002) (Fig. 1). Indeed, large phytoplankton communities seem to dominate in productive ecosystems thanks to their physical and chemical capacities to escape to zooplankton grazing (Irigoien et al., 2004, 2005). Furthermore, it has been observed that large phytoplankton dominate in the high turbulence regime (Rodríguez et al., 2001; Li, 2002) and that when nitrogen supply is pulsed, large cells could dominate due to their enhanced storage capacities (Litchman et al., 2009).

This leaves a scenario (Fig. 1) where nutrient-limited ecosystems are dominated by fast-growing, small phytoplankton cells, while high-nutrient environments are dominated by slow-growing, large phytoplankton species. As a result, it is possible to reach the counterintuitive result that the community growth rate $\left(\mu_{\mathrm{com}}\right)$, i.e. the mean growth rate of the phytoplankton cells in a community, can be higher when nutrients are limited (Fig. 1). Franks (2009) contended the common practice in marine ecosystem models to parameterize phytoplankton community growth rates using MichaelisMenten kinetics. Following our conceptual argumentation, it is indeed quite likely that the response of community growth rate is different to that of individual species.

In this study, we use a database of in situ phytoplankton community growth rate measurements in surface waters of 


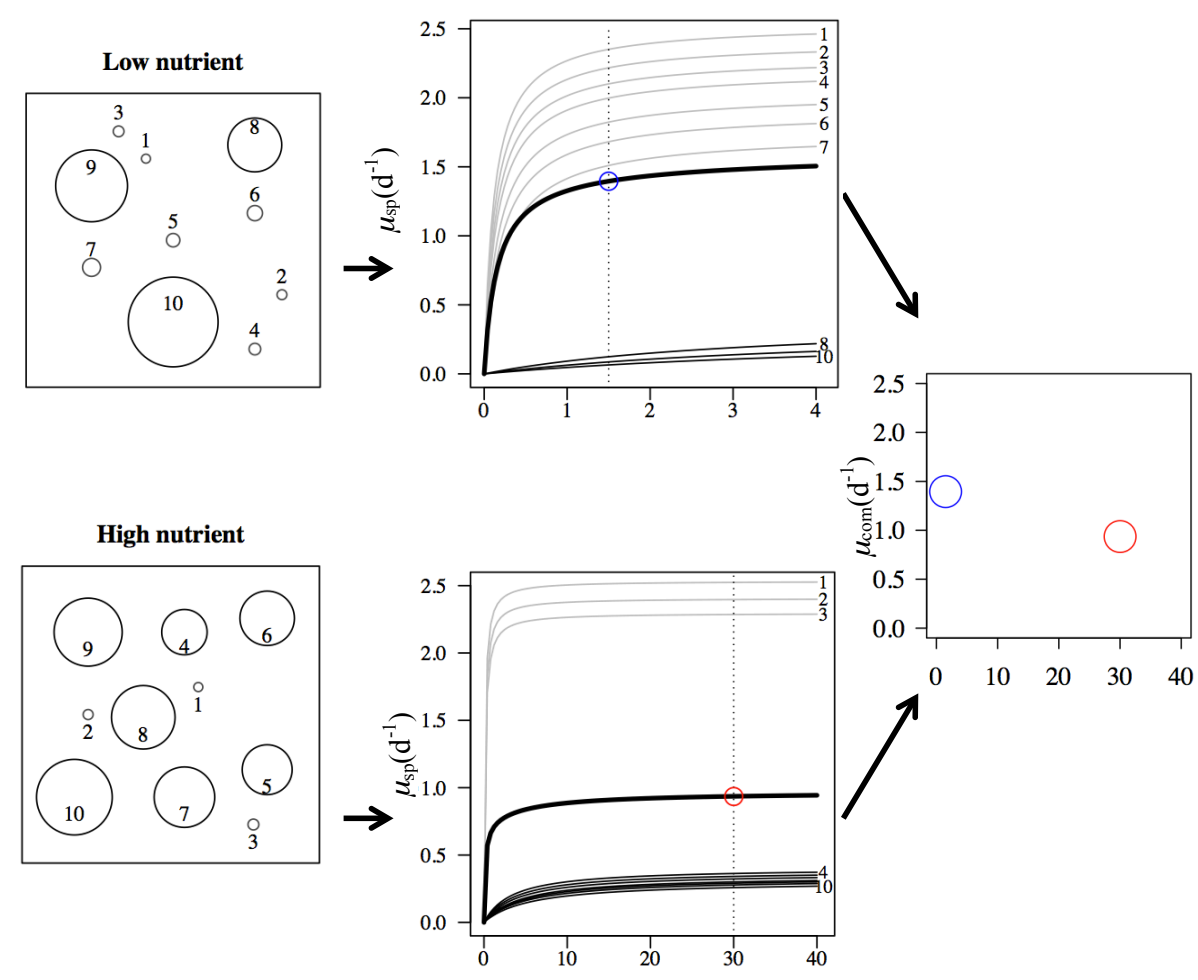

Figure 1. Conceptual diagram representing phytoplankton communities composed of small and large phytoplankton species (small grey and large black circles, respectively) in nutrient-limited and productive ecosystems. Each phytoplankton species composing their respective communities had its own growth rate response to nutrient concentration following a Monod kinetic. The growth rates for the whole community in both ecosystems have been evaluated by the mean of the cell-specific growth rates of each phytoplankton species composing their respective communities. At the bottom of the diagram, community growth rates for both ecosystems are represented at specific nutrient concentrations.

the global ocean covering oligotrophic as well as productive ecosystems and test the hypothesis that the response of phytoplankton community growth rates to nutrient concentration does not follow Monod kinetics. We also develop a simple statistical model summarizing our conceptual framework (Fig. 1). We first parameterize, using in situ phytoplankton size structure data (Marañón et al., 2012), the steeper phytoplankton size spectra slope when nutrient concentrations are low. We then combine this size structure information with simple allometric equations describing the response of phytoplankton species growth to nutrients (Edwards et al., 2012) and calculate the predicted response of phytoplankton community growth rates to nutrients.

\section{Methods}

\subsection{In situ community growth data}

We used an independent data set containing phytoplankton in situ growth rate measurements in surface waters of the ocean compiled by Chen and Liu (2010) (see Chen and Liu (2010) Web appendix, Table A1, http://www.aslo.org/lo/toc/vol_55/ issue_3/0965a.html). We refer here to community growth rate $\left(\mu_{\mathrm{com}}\right)$ as the specific growth rate measured in a dilution experiment which represents the average biomass-specific growth rates of the cells in a phytoplankton community. The data set covers open ocean, coastal regions as well as highnutrient, low-chlorophyll (HNLC) areas and is restricted to experiments conducted in surface waters to reduce the effects of light limitation. The results described here represent the whole data set, including HNLC. We removed from the original data set all data for which nitrate concentration was below the detection limit or lower than $0.01 \mu \mathrm{mol} \mathrm{L}-1$. The database compiles data from experiments based on the dilution technique (Landry and Hassett, 1982) to estimate in situ phytoplankton community growth rate $\left(\mu_{\mathrm{com}}, \mathrm{d}^{-1}\right)$. Two different estimates of phytoplankton community growth rates are obtained in dilution experiments: nutrient amended or maximum growth rate $\left(\mu_{\text {com_max }}\right)$ and non-amended or growth rate $\left(\mu_{\text {com }}\right)$ under natural conditions.

If the in situ community growth rate $\left(\mu_{\mathrm{com}}\right)$ responds to the nutrient concentration following Monod's equation, we could formulate:

$\mu_{\text {com }}=\frac{S}{S+K_{\mathrm{s}}} \mu_{\text {com_max }}$,

where $S$ is the nutrient concentration (e.g. nitrate, phosphate, silicate, iron and so on) and $K_{\mathrm{S}}$ is the half-saturation constant for that nutrient. 
The population maximum growth rate $\left(\mu_{\text {com_max }}\right)$ is the growth rate measured when the population is not limited by nutrients and depends directly on the same parameters than the growth rate but nutrient concentration.

$\mu_{\text {com_max }}=f(T$, PAR, s.s., d.1., s.c., $\ldots)$,

where $T$ is the temperature, PAR is the photosynthetically active radiation, s.s. is the species size, d.l. is the day length, and s.c. is the species composition.

Thus, the ratio $\mu_{\text {com }}: \mu_{\text {com_max }}$ is a direct index of nutrient-limited growth (Brown et al., 2002), also called relative reproductive rate $\left(\mu_{\text {com_rel }}\right)$ (Sommer, 1991).

$$
\begin{aligned}
& \mu_{\text {com_rel }}=\frac{\mu_{\text {com }}}{\mu_{\text {com_max }}} \\
& \mu_{\text {com_rel }}=\frac{S}{S+K_{\mathrm{S}}}
\end{aligned}
$$

\subsection{Community growth rate model description}

We simulate the growth rate of a community under different nutrient concentrations. For that we used a database containing size structure information for 423 different phytoplankton communities (Marañón et al., 2012). For simplicity, only one nutrient (nitrogen) was considered to be limiting. In our simulations, the phytoplankton community is composed by 55 phytoplankton species ranging in cell size from 0.33 to $5 \times 10^{5} \mu \mathrm{m}^{3}$ of volume. This size range encompasses the whole phytoplankton species size range observed in situ, from prochlorococcus size (Partensky et al., 1999) to the largest diatoms (Agustí et al., 1987). The size-abundance spectrum slope determined the relative abundance of each species. Because size spectra slope varies depending on the trophic state of the system, we empirically derived a relationship between size spectra slope and nutrient concentration (see Sect. 2.3). Indeed, Platt and Denman (1977) exposed the use of a property of the biomass size in that the normalized biomass is an estimate of the number of density of organisms in each size class. Although this should be considered an approximation (Blanco et al., 1994), we used the changes in scaling of normalized biomass with different nutrient levels to simulate the changes in the size scaling of the numerical abundance of species at different nutrient levels. The community growth rate is the average growth rate of all the cells within the community and is calculated as the mean growth rate of the 55 phytoplankton species weighted by the total biomass of each species. This rate is equivalent to the growth rate measured experimentally as the rate of total community in situ growth rate ( $\mu$, in the dilution data set).

\subsection{Parameterization of the size-spectrum dependence on resource levels with in situ size structure data}

Chlorophyll $a$ (Chl $a)$ data for three different size classes $(0.2-2,2-20$, and $>20 \mu \mathrm{m})$ were collected from Marañón et al. (2012). Like Sprules and Munawar (1986), we used the Chl $a$ data to calculate the normalized biomass spectrum (NBSS) by regressing the logarithm of the normalized chlorophyll by biovolume. The biovolume was calculated using the volume equation of a sphere (Hillebrand et al., 1999). Nutrient concentration $\left(\Sigma, \mu \mathrm{mol}\left(\mathrm{NO}^{3}+\mathrm{NO}^{2}\right) \mathrm{L}^{-1}\right)$ for each station of the Chl $a$ data set was estimated from the nitrate climatology in the World Ocean Atlas 2009 (WOA). We then fitted a model describing the effects of nutrient concentration on NBSS.

\subsection{Parameterization of species size-dependent nutrient resource acquisition and growth rate}

The dependence of growth rate $(\mu)$ on ambient nutrient concentration is usually modelled using the Droop model (Droop, 1973). Aksnes and Egge (1991) developed a theoretical framework that explains how cell size should affect the parameters in the Droop model. This theoretical prediction was demonstrated with experimental data by Litchman et al. (2006). Edwards et al. (2012) estimated the allometric parameters for $V_{\max }$ (the maximum cell-specific nutrient uptake rate, $\mu$ mol nutrient cell ${ }^{-1} \mathrm{~d}^{-1}$ ) and $K_{\mathrm{m}}$ that we use here in our model (Fig. 2b):

$\log _{10}\left(V_{\max }\right)=-8.1+\log _{10}(\mathrm{Vol}) \times 0.82$

$\log _{10}\left(K_{\mathrm{m}}\right)=-0.84+\log _{10}(\mathrm{Vol}) \times 0.33$,

where Vol is the cell volume $\left(\mu \mathrm{m}^{3}\right)$ and $K_{\mathrm{m}}$ is the nutrient concentration where $V=V_{\max } / 2$ (Litchman et al., 2009).

To reach an estimate of a relationship between $\mu$ and $S$ using the Droop model requires the solution of a set of differential equations. Because our intention is only to evaluate the possible effects that a nutrient dependence formulation can have on the determination of community growth rates, we have followed a simpler approach by using relative uptake rate as a proxy for growth rate (Aksnes and Egge, 1991). Hence we have formulated the relative uptake rate $\left(V_{\text {rel }}, \mathrm{d}^{-1}\right)$ as:

$V_{\text {rel }}=\mu_{\mathrm{sp}}=V_{\max } \frac{S}{Q\left(K_{\mathrm{m}}+S\right)}$,

where $\mu_{\mathrm{sp}}$ is the growth rate $\left(\mathrm{d}^{-1}\right)$, the subscript "sp" is used to differentiate the monospecific growth rate $\left(\mu_{\mathrm{sp}}\right)$ from the multispecific community-average growth rate $\left(\mu_{\text {com }}\right)$ as measured in dilution experiments, $Q$ is the cell nutrient content ( $\mu$ mol of nutrient cell ${ }^{-1}$ ) and $V_{\max }$ is the maximum uptake rate constrained by diffusion in the boundary layer outside the cell. In Eq. (6), $V_{\max }$ and $K_{\mathrm{m}}$ are calculated from cell size using Eqs. (4) and (5). To estimate $Q$, we follow Aksnes and Egge (1991) in assuming biomass as the average number of atoms of a given element within the cell, estimated from cell carbon content using a carbon-to-volume ratio $\left(\mathrm{C}: V_{\text {ratio }}\right)$ 

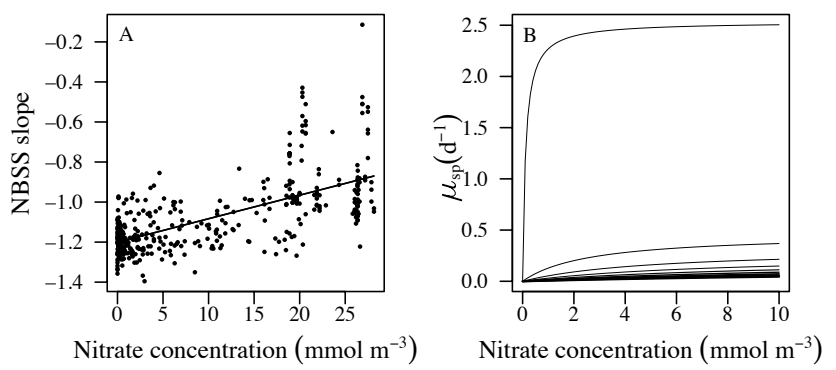

Figure 2. Functional forms of (a) normalized biomass spectrum (NBSS) and (b) phytoplankton species growth rate to nutrient concentration. (b) Simple allometric equations are indicated by the size range from small (thinnest lines) to large (thickest lines) size species. (a) The solid line represents the linear regression.

of $0.28 \mathrm{pg} \mathrm{C} \mu \mathrm{m}^{3}$ based on the empirical equation given in Litchman et al. (2007) and a Redfield ratio of 106 C: $16 \mathrm{~N}$. The implications of these assumptions are evaluated in the discussion.

The community-average growth rate $\left(\mu_{\mathrm{com}}\right)$ as measured in dilution experiments can be calculated from knowledge of the monospecific growth rate for each of the species in the community $\mu_{\mathrm{sp}_{\mathrm{i}} \mathrm{i}}$ and the biomass of each species in the community which can be calculated from the numerical abundance times the species cell carbon content. The community biomass at the beginning of the dilution experiment $\left(B_{\text {initial }}\right)$ is:

$$
\begin{aligned}
& B_{i}=N_{i} \times C_{i} \\
& B_{\text {initial }}=\sum_{n}^{i=1} B_{i},
\end{aligned}
$$

where $B_{i}$ is the biomass $\left(\mathrm{g} \mathrm{C} \mathrm{mL}^{-1}\right), N_{i}$ is the numerical abundance (cell $\mathrm{mL}^{-1}$ ) and $C_{i}$ the cell carbon content $\left(\mathrm{g} \mathrm{C} \mathrm{cell}^{-1}\right)$ of each species in the community.

At the end of the experiment (assuming a $24 \mathrm{~h}$ experiment in the absence of grazing), the biomass $\left(B_{\text {final }}\right)$ would be:

$B_{\text {final }}=\sum_{n}^{i=1}\left(B_{i} \exp ^{\mu_{\mathrm{sp}_{i}} \times t}\right)$

where $t$ is the duration of experiment $\left(\mathrm{d}^{-1}\right)$.

The predicted community growth rate is so defined as:

$\mu_{\text {com }}=\frac{\log \left(\frac{B_{\text {final }}}{B_{\text {initial }}}\right)}{t}$.

\section{Results}

\subsection{In situ data}

In situ phytoplankton community growth rates $\left(\mu_{\mathrm{com}}\right)$ do not respond to nutrient variation following Monod's kinet-
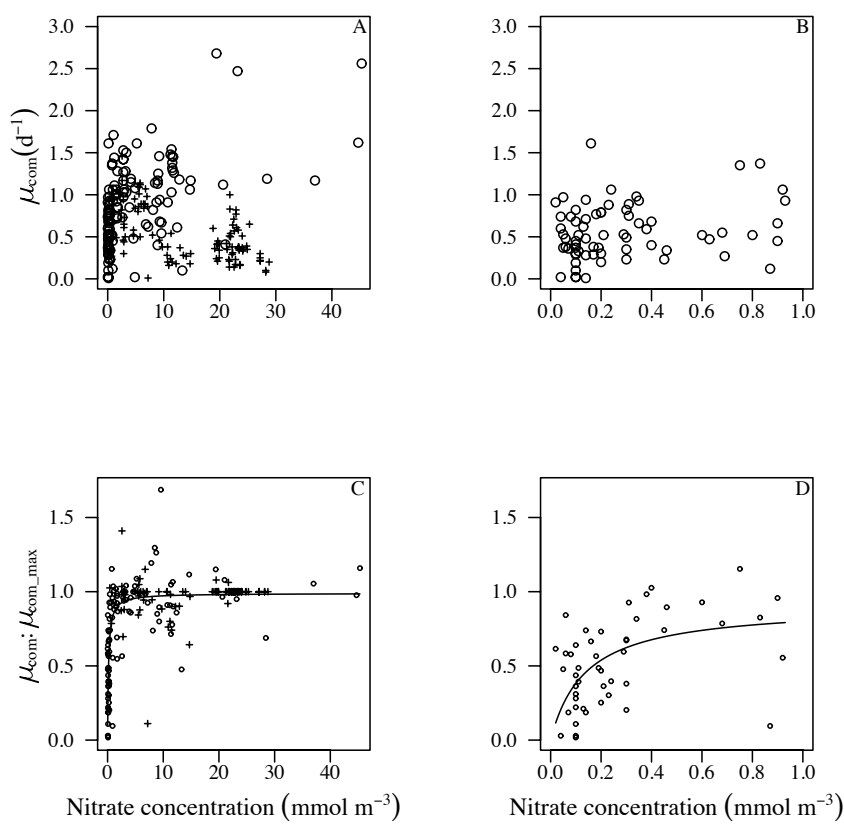

Figure 3. Relationships between in situ community growth rate $\left(\mu_{\text {com }}, \mathrm{d}^{-1}\right.$ ) and nutrient concentration (a) from 0 to $40 \mathrm{mmol} \mathrm{m}^{-3}$ and (b) from 0 to $1 \mathrm{mmol} \mathrm{m}^{-3}$. Relationships between in situ $\mu_{\text {com }}: \mu_{\text {com } \max }$ ratio and nutrient concentration (c) from 0 to $40 \mathrm{mmol} \mathrm{m}^{-3}$ and (d) from 0 to $1 \mathrm{mmol} \mathrm{m}^{-3}$. Crosses represent phytoplankton communities of Table A1 sampled in HNLC regions and circles represent the rest of the phytoplankton communities from Table A1 data set. (c, d) The solid lines represent the nonlinear least square fits for the global data set (HNLC included).

ics (Fig. 3a). The correlation between in situ $\mu_{\text {com }}$ and estimated in situ nutrient concentration was non significant $\left(R^{2}=0.01, p=0.2849\right)$. The response of the growth rate to nutrient concentration is often considered to follow a Monod model when phytoplankton community is limited by nutrient (below $1 \mu \mathrm{mol} \mathrm{L}{ }^{-1}$ ). In our data set, for nutrient concentrations below $1 \mu \mathrm{mol} \mathrm{L} \mathrm{L}^{-1}$, in situ phytoplankton community growth rate does not respond to nutrient concentration either $\left(R^{2}=0.05, p=0.0578\right.$, Fig. 3b). Even if data are corrected for temperature effects (using the ArrheniusBoltzmann equation with an activation energy of $-0.33 \mathrm{eV}$, López-Urrutia et al., 2006), the in situ community growth rate did not follow Monod kinetics (Fig. 4). However, our results show that the in situ $\mu_{\text {com }}: \mu_{\text {com_max }}$ ratios (or $\mu_{\text {com_rel }}$ ) do indeed follow a Monod model with $K_{\mathrm{S}}=0.16 \pm 0.02$ and $\mu_{\text {com_rel_max }}=0.99 \pm 0.02$ (Fig. 3c). For nutrient concentration below $1 \mu \mathrm{mol} \mathrm{L}{ }^{-1}$, in situ $\mu_{\text {com_rel }}$ also follows Monod's growth kinetics with $K_{\mathrm{S}}=0.14 \pm 0.06$ and $\mu_{\text {com_rel_max }}=$ $0.91 \pm 0.14$ (Fig. 3d).

\subsection{Simulation}

A linear model of NBSS vs. nutrient concentration explained $43 \%$ of the variance with an increasing size spec- 


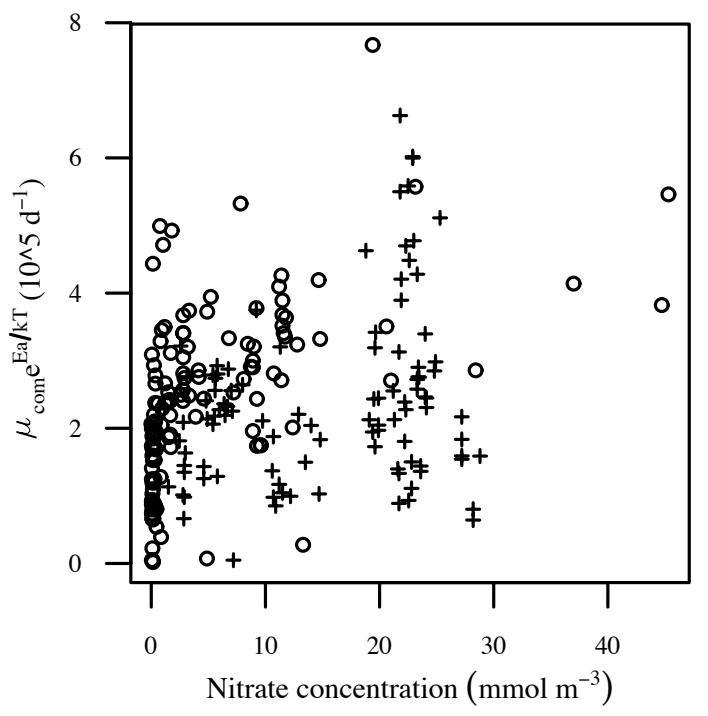

Figure 4. Relationship between in situ community growth rates $\left(\mu_{\text {com }} e^{\mathrm{Ea} / \mathrm{KT}}, \mathrm{d}^{-1}\right)$ corrected by temperature using the average activation energy for autotrophic respiration $(\mathrm{Ea}=-0.33 \mathrm{eV}$; LópezUrrutia et al., 2006) and nitrate concentration $\left(\mathrm{mmol} \mathrm{m}^{-3}\right)$. Crosses represent phytoplankton communities of Table A1 sampled in HNLC regions and circles represent the rest of the phytoplankton communities from the Table A1 data set.

tra slope (i.e. less negative NBSS) with increasing nutrient concentration (Fig. 2a). Each species composing the simulated phytoplankton community was limited by nutrient and responded to the nutrient concentration following Monod's model. However, the predicted community growth rate $\left(\mu_{\text {com_predicted }}\right)$ for the simulated communities did not follow Monod kinetics (Fig. 5a). On the contrary, and similar to in situ results, the predicted $\mu_{\text {com_rel }}$ was well in accordance with Monod's model (Fig. $5 \mathrm{~b}, K_{\mathrm{s}}=0.11 \pm 0.01$ and $\left.\mu_{\text {com_rel_max }}=0.98 \pm 0.01\right)$.

\section{Discussion}

In this study, we observed that in situ phytoplankton community growth rate does not respond to nutrient concentration following a Monod kinetic as phytoplankton species composing the community do. However, for the relative reproductive rates, the Monod model is a good characterization of community dynamics.

The lack of significant response following a Monod kinetic may be explained by factors other than nitrate concentration limiting phytoplankton community growth rate. Indeed, we observed that from the total 242 in situ phytoplankton community growth rate data, 110 were from HNLC oceanic regions and thus under iron limitation. If the data from HNLC zones are removed from our analysis, we observe that the relationship between phytoplankton community growth rate and nitrate concentration is closer to follow- ing a Monod kinetic than when considering the whole data set $\left(R^{2}=0.43, p<0.05\right)$. The iron limitation may partly explain the lack of Monod kinetic between the in situ phytoplankton community growth rate and nitrate concentration presented here. However, we observed that in situ phytoplankton community growth rate does not respond to nutrient concentration following a Monod kinetic at nutrient concentrations below $1 \mu \mathrm{mol} \mathrm{L}{ }^{-1}$ although these data do not correspond to iron-limited HNLC regions. The estimation of phytoplankton growth rate by dilution experiments in the most oligotrophic regions may be biased and have to be treated with caution. Indeed, Latasa et al. (2014) explained that most of the studies determining phytoplankton growth rate from dilution experiments presented regression slopes between apparent phytoplankton growth rate and dilution different from zero when the null hypothesis to be tested in dilution experiment should be the positive slope $(b<0)$ and not a null slope $(b=0)$. Latasa and co-workers believed that a proportion of the experiments with non-significant regressions were disregarded eliminating ecological situations of low growth and grazing. This may result in an overestimation of phytoplankton growth rates.

Although the presented patterns from dilution experiments have to be treated with caution considering the iron limitation at high nutrient concentration and the possible overestimation of phytoplankton growth rate at low nutrient concentration, we observed similar results from in situ phytoplankton community growth rate determined by another methodology. Indeed, we analysed the response of the in situ phytoplankton community growth rate calculated from primary production and standing stocks (Chen and Liu, 2010) and nitrate concentration (Fig. 6). As we observed for the dilution experiment, the in situ phytoplankton community growth rate does not respond to nitrate concentration following a Monod kinetic both considering and excluding data from HNLC zones $\left(R^{2}=0.17, p<0.05\right.$ and $R^{2}=0.06, p<0.05$ respectively). This result confirms our previous observation of the lack of Monod kinetic between in situ phytoplankton community growth rate and nutrient concentration. Unfortunately, the primary production data were not analysed under nutrient amended and the maximum growth rate could not have been estimated.

The marine biogeochemical models in use are composed of three or four compartments (i.e. nutrient phytoplankton zooplankton, NPZ or nutrient phytoplankton zooplankton detritus, NPZD) (McCreary et al., 2001; Hood et al., 2003; Kantha, 2004) to 20 or more components including different phytoplankton functional groups, various nutrients and so on (Anderson, 2005; Lancelot et al., 2005; Le Quéré et al., 2005). The NPZ and NPZD models describe a simple food web system assuming dissolved nutrients are consumed by the phytoplankton community following Monod kinetics. For these models, the phytoplankton compartment is considered as a whole community and assumed to respond to nutrient concentration as phytoplankton species do. As we observed 

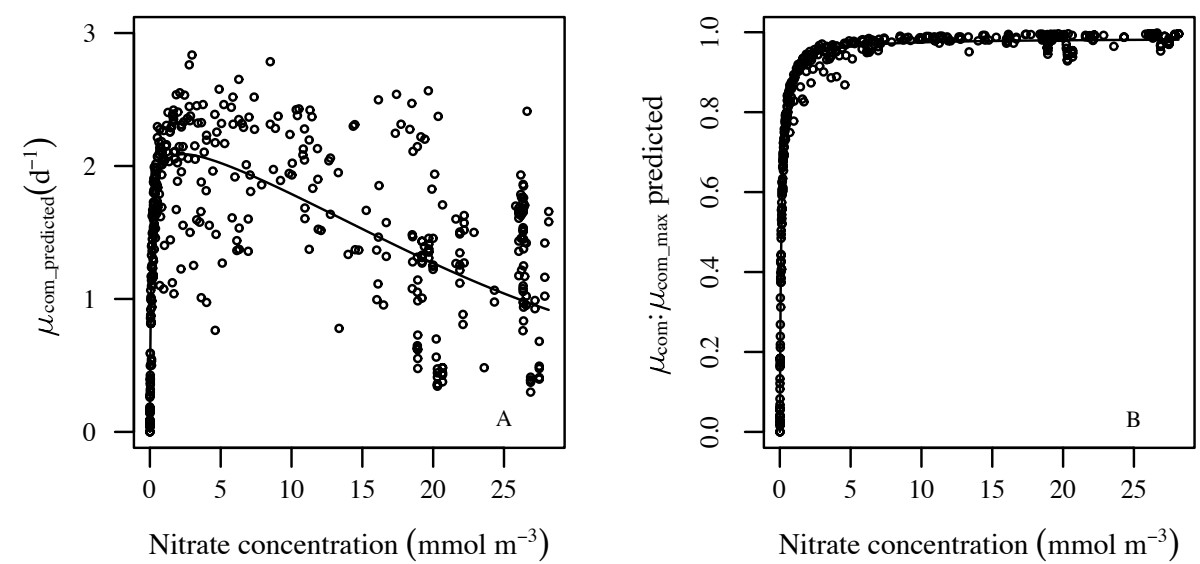

Figure 5. Relationships between (a) predicted community growth rate $\left(\mu_{\text {com_predicted }}, \mathrm{d}^{-1}\right)$ and (b) predicted $\mu_{\text {com }}: \mu_{\text {com_max }}$ ratio, and nutrient concentration $\left(\mathrm{mmol} \mathrm{m}^{-3}\right)$. The solid lines represent the nonlinear least square fits.
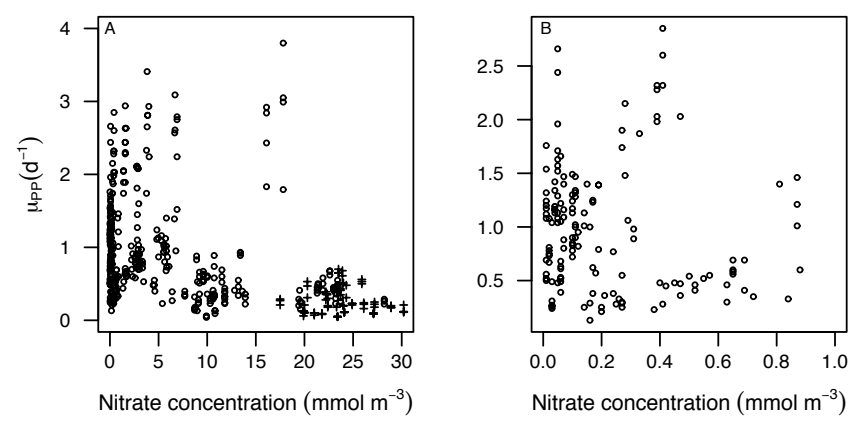

Figure 6. Relationships between in situ community growth rates $\left(\mu_{\mathrm{PP}}, \mathrm{d}^{-1}\right)$ estimated from primary production and standing stocks and nitrate concentration (a) from 0 to $40 \mathrm{mmol} \mathrm{m}^{-3}$ and (b) from 0 to $1 \mathrm{mmol} \mathrm{m}^{-3}$ from Chen and Liu (2010) Table A2 data set. Crosses represent phytoplankton communities of Table A2 sampled in HNLC regions and circles represent the rest of the phytoplankton communities from the Table A2 data set.

in this study, the in situ and predicted phytoplankton communities do not necessarily respond to nutrient concentration like individual phytoplankton. Thus, marine biogeochemical models using different phytoplankton functional groups (Anderson, 2005; Le Quéré et al., 2005) or based on phytoplankton size structure (Follows et al., 2007; Edwards et al., 2012) should be used instead of simpler models as NPZ or NPZD. This is well in line with the findings of Friedrichs et al. (2006, 2007) that observed that complex models with multiple phytoplankton functional groups fit the available data better than the simpler models. This is mainly due to the use of many tuning parameters and thus degrees of freedom. The parameterization of planktonic ecosystem models should not use the same variables for a community as for species. Franks (2009) warned about the use of community variables parameterized using data from individual species and suggested that the response to nutrient concentration of an individual or species should not necessarily represent the response of a diverse community. Contrary to our results, Franks (2009) observed a linear relation between the community nutrient uptake rate and nutrient concentration that could be explained by the use of the same half-saturation constant $\left(K_{\mathrm{S}}\right)$ for all phytoplankton size classes in his simulations. Several published works reported that $K_{\mathrm{S}}$ is different between species (Sommer, 1991; Chisholm, 1992; Cermeño et al., 2011). In our study, the relationship between the in situ community growth rate and nutrient concentration did not follow a Monod kinetic, or a linear relationship.

Many models (e.g. Darwin model) use a trade-off between $K_{\mathrm{S}}$ and $\mu_{\max }$ - some organisms grow fast at high nutrient concentrations (high $V_{\max }$ or $\mu_{\max }$ ) and others may be better competitors at low nutrient concentrations with low $K_{\mathrm{s}}$. Without this trade-off, small phytoplankton would outcompete large phytoplankton in the whole ocean unless other constraints are introduced (e.g. top-down differences). Although this trade-off would maintain species coexistence in a competition model, this theoretical perspective is in contrast with the empirical evidence on the size dependence of $K_{\mathrm{S}}$ and $\mu_{\max }$. Indeed, the most up-to-date compilations on the size dependence of $K_{\mathrm{S}}$ and $\mu_{\max }$ do not reveal the existence of a trade-off between these two variables. Edwards et al. (2012) found that $K_{\mathrm{S}}$ increases with increasing cell size and $V_{\max }$ and $\mu_{\max }$ decrease with increasing size. Furthermore, Fiksen et al. (2013) were unable to identify any mechanistic tradeoff conflicts between $K_{\mathrm{S}}$ and $V_{\max }$. In this work, we decided to parameterize empirical phytoplankton growth rate and size (Fig. 1) without accounting for the trade-off between $K_{\mathrm{S}}$ and $\mu_{\max }$ considering that recent empirical data do not reveal its existence.

Several studies have shown that the high surface area to volume $(S: V)$ ratio of small phytoplankton species results in high maximum nutrient uptake rates and low $K_{\mathrm{S}}$ and may explain why small phytoplankton species dominate in natu- 
ral nutrient-limited ecosystems (Eppley et al., 1969; Aksnes and Egge, 1991; Hein et al., 1995). Conversely, large phytoplankton species seem to dominate in productive and wellmixed ecosystems (Irwin et al., 2006) due to their physical and chemical capacities to escape to zooplankton grazing (Irigoien et al., 2004, 2005) and due to upward motion increasing their residence time in the upper layer against their tendency to sink (Li, 2002; Rodríguez et al., 2001). Furthermore, allometric equations explain that a small phytoplankton species achieves higher growth rate than a large phytoplankton species at the same nutrient concentration (Edwards et al., 2012). Considering the allometric equations and the low nutrient-small phytoplankton and high nutrientlarge phytoplankton relations, the community growth rate can be higher at low than at high nutrient concentration. We observed in this study that most of the community growth rates tended to decrease from 5 to $30 \mathrm{mmol} \mathrm{NO}{ }^{3}+\mathrm{NO}^{2} \mathrm{~m}^{-3}$ (Fig. 3a) for the in situ data $\left(R^{2}=0.15, p<0.001\right)$ and from 2.5 to $25 \mathrm{mmol} \mathrm{NO}^{3}+\mathrm{NO}^{2} \mathrm{~m}^{-3}$ (Fig. 5a) for the predicted data $\left(R^{2}=0.17, p<0.001\right)$. Therefore, our results support our hypothesis of higher community growth rates at intermediate than at the highest nutrient concentrations.

In our simulation, we assumed that the intrinsic nutrient storage is related to the growth rate and ignored, for the sake of simplicity in the simulations of the cell storage capacity. Indeed, Litchman et al. (2009) observed that when nitrogen supply is pulsed, large cells could dominate due to their enhanced storage capacities. By this observation, we should expect to observe higher growth rates for large phytoplankton species at high nutrient concentration than for small phytoplankton species, but if so a better relationship between community growth rate and nutrient concentration would be expected. The relationship between $\mu_{\text {sp_max }}$ and cell volume might influence the kinetic of the community growth rate response to nutrient concentration. Although there is consensus on the fact that smaller cells have lower half-saturation constants, the relationship between $\mu_{\text {sp_max }}$ and cell size is still under debate (Chen and Liu, 2011; Sal and López-Urrutia, 2011). Two different relations have been observed between $\mu_{\text {sp_max }}$ and cell volume: unimodal (Bec et al., 2008; Chen and Liu, 2011; Marañón et al., 2013) and declined lineal (Edwards et al., 2012). In addition, the parameterizations of some models argue for an increased lineal relationship (Follows et al., 2007). To understand the consequences of different relationships between $\mu_{\text {sp_max }}$ and cell size, we repeated our simulations but using unimodal (Fig. 7a) and positive (Fig. 7b) relationships between $\mu_{\text {sp_max }}$ and cell size. We observed that when the relation between $\mu_{\text {sp_max }}$ and cell volume is unimodal, the predicted community growth rates did not follow Monod's kinetic either (Fig. 7a). When the relation between $\mu_{\text {sp_max }}$ and cell volume is positive (i.e. larger cells have higher $\mu_{\text {sp_max }}$ ), the model output suggests a possible relation between the predicted community growth rates and nutrient concentration (Fig. 7b). Hence, the observed lack of relationship in the in situ data (Fig. 3a) could be re-
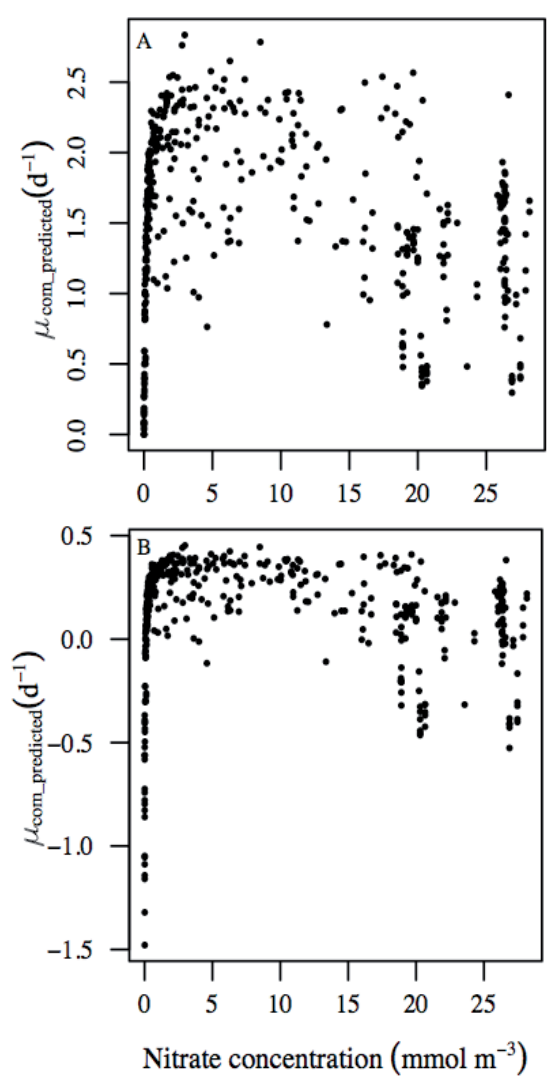

Figure 7. Relationships between the predicted community growth rates $\left(\mu_{\text {com_predicted }}, \mathrm{d}^{-1}\right)$ and nitrate concentration $\left(\mathrm{mmol} \mathrm{m}^{-3}\right)$ with (a) unimodal and (b) positive relationships between $\mu_{\text {com_max }}$ and cell size.

produced with the unimodal but not with the positive relationship.

Although community growth rates did not respond to nutrient concentration following Monod kinetics, the in situ and simulated $\mu_{\text {com_rel }}$ did (Figs. $3 b, 5 b$ ). The $\mu_{\text {com_rel }}$ is exempted from the effects of temperature, light and community composition. The $K_{\mathrm{S}}$ and $\mu_{\text {com_rel_max }}$ were quite similar between the in situ $\left(K_{\mathrm{S}}=0.16 \pm 0.02\right.$ and $\mu_{\text {com_rel_max }}=0.99 \pm$ $0.02)$ and predicted $\left(K_{\mathrm{S}}=0.11 \pm 0.01\right.$ and $\mu_{\text {com_rel_max }}=$ $0.98 \pm 0.01) \mu_{\text {com_rel }}$. So when the community growth rate depends only on nutrient concentration, the response of the community growth rate to nutrient variation follows the predicted Monod kinetic.

In summary, our study demonstrates that the lack of relationship between community growth rates and nutrients can be explained even if we disregard the effects of temperature, light or community composition. We could expect that such factors might further distort the observed relationship between the community growth rate and nutrient concentration. 
Acknowledgements. This work was supported by Metabolic Ocean Analysis (METOCA) funded by the Spanish National Invsetigation + Development + Innovation $(\mathrm{I}+\mathrm{D}+\mathrm{I})$ Plan. We thank E. Marañón for sharing his phytoplankton size structure data and Ángel Segura for his useful comments and corrections. This is a contribution to times series project RADIALES from the Instituto Español de Oceanografía (IEO).

Edited by: G. Herndl

\section{References}

Agustí, S., Duarte, C. M., and Kalff, J.: Algal cell size and the maximum density and biomass of phytoplankton, Limnol. Oceanogr., 32, 983-986, 1987.

Aksnes, D. L. and Egge, J. K.: A theoretical model for nutrient uptake in phytoplankton, Mar. Ecol.-Prog. Ser., 70, 65-72, 1991.

Anderson, T. R.: Plankton functional type modeling: running before we can walk?, J. Plankton Res., 27, 1073-1081, doi:10.1093/plankt/fbi076, 2005.

Bec, B., Collos, Y., Vaquer, A., Mouillot, D., and Souchu, P.: Growth rate peaks at intermediate cell size in marine photosynthetic picoeukaryotes, Limnol. Oceanogr., 53, 863-867, 2008.

Blanco, J. M., Echevarría, F., and García, C. M. : Dealing with sizespectra: Some conceptual and mathematical problems, Sci. Mar., 58, 17-29, 1994.

Brown, S. L., Landry, M. R., Christensen, S., Garrison, D., Gowing, M. M., Bidigare, R. R., and Campbell, L.: Microbial community dynamics and taxon-specific phytoplankton production in the Arabian Sea during the 1995 monsoon seasons, Deep-Sea Res., 49, 2345-2376, 2002.

Cermeño, P., Lee, J.-B., Wyman, K., Schofield, O., and Falkowski, P. G.: Competitive dynamics in two species of marine phytoplankton under non-equilibrium conditions, Mar. Ecol.-Prog. Ser., 429, 19-28, 2011.

Chen, B. Z. and Liu, H. B.: Relationships between phytoplankton growth and cell size in surface oceans: Interactive effects of temperature, nutrients, and grazing, Limnol. Oceanogr., 55, 965972, 2010.

Chen, B. Z. and Liu, H. B.: Comment: Unimodal relationship between phytoplankton-mass-specific growth rate and size: A reply to the comment by Sal and López-Urrutia (2011), Limnol. Oceanogr., 56, 1956-1958, 2011.

Chisholm, S. W.: Phytoplankton size, in: Primary productivity and biogeochemical cycles in the sea, Plenum Press, edited by: Falkowski, P. G. and Woodhead, A. D., 213-237, 1992.

Droop, M. R.: Some thoughts on nutrient limitation in algae, J. Phycol., 9, 264-272, 1973.

Dugdale, R. C.: Nutrient limitation in the sea: dynamics, identification, and significance, Limnol. Oceanogr., 12, 685-695, 1967.

Edwards, K. F., Thomas, M. K., Klausmeier, C. A., and Litchman, E.: Allometric scaling and taxonomic variation in nutrient utilization traits and maximum growth rate of phytoplankton, Limnol. Oceanogr., 57, 554-566, 2012.

Eppley, R. W., Rogers, J. N., and McCarthy, J. J.: Half-saturation constants for uptake of nitrate and ammonium by marine phytoplankton, Limnol. Oceanogr., 14, 912-920, 1969.
Fiksen, Ø, Follows, M. J., and Aksnes, D. L.: Trait-based models of nutrient uptake in microbes extend the Michaelis-Menten framework, Limnol. Oceanogr., 58, 193-202, 2013.

Follows, M. J., Dutkiewicz, S., Grant, S., and Chisholm, S. W.: Emergent biogeography of microbial communities in a model ocean, Science, 315, 1843-1846, 2007.

Franks, P. J.: Planktonic ecosystem models: Perplexing parameterizations and a failure to fail, J. Plankton Res., 31, 1299-1306, 2009.

Friedrichs, M. A. M., Hood, R., and Wiggert, J.: Ecosystem model complexity versus physical forcing: Quantification of their relative impact with assimilated Arabian Sea data, Deep-Sea Res. Pt. II, 53, 576-600, 2006.

Friedrichs, M. A. M., Dusenberry, J. A., Anderson, L. A., Armstrong, R. A. A., and Chai, F.: Assessment of skill and portability in regional marine biogeochemical models: Role of multiple planktonic groups, J. Geophys. Res., 112, C08001, doi:10.1029/2006JC003852, 2007.

Grover, J. P.: Influence of cell shape and size on algal competitive ability, Am. Nat., 138, 811-835, 1989.

Hein, M., Pedersen, M. F., and Sand-Jensen, K.: Size-dependent nitrogen uptake in micro- and macroalgae, Mar. Ecol. Prog. Ser., 118, 247-253, 1995.

Hillebrand, H., Dürselen, C.-D., Kirschtel, D., Pollinger, U., and Zohary, R.: Biovolume calculation for pelagic and benthic microalgae, J. Phycol., 35, 403-424, 1999.

Hood, R. R., Kohler, K. E., McCreary, J. P., and Smith, S. L.: A fourdimensional validation of a coupled physical-biological model of the Arabian Sea, Deep Sea Res. Pt. II, 50, 2917-2945, 2003.

Irigoien, X., Huisman, J., and Harris, R. P.: Global biodiversity patterns of marine phytoplankton and zooplankton, Nature, 429, 863-867, 2004.

Irigoien, X., Flynn, K. J., and Harris, R. P.: Phytoplankton blooms: A "loophole" in microzooplankton grazing impact?, J. Plankton Res., 27, 313-321, 2005.

Irwin, A. J., Finkel, Z. V., Schofield, O. M. E., and Falkowski, P. G.: Scaling-up from nutrient physiology to the size-structure of phytoplankton communities, J. Plankton Res., 28, 459-471, 2006.

Kantha, L. H.: A general ecosystem model for applications to studies of carbon cycling and primary productivity in the global oceans, Ocean Modell, 6, 285-334, 2004.

Lancelot, C., Spitz, Y., Gypens, N., Ruddick, K., Becquevort, S., Rousseau, V., Lacroix, G., and Billen, G.: Modelling diatomPhaeocystis blooms and nutrient cycles in the Southern Bight of the North Sea: The MIRO model, Mar. Ecol.-Prog. Ser., 289, 63$78,2005$.

Landry, M. R. and Hassett, R. P.: Estimating the grazing impact $\mathrm{f}$ marine micro-zooplankton, Mar. Biol., 67, 283-288, 1982.

Latasa, M.: Comment: a potential bias in the databases of phytoplankton growth and microzooplankton grazing rates because of the improper formulation of the null hypothesis in dilution experiments, Limnol. Oceanogr., 59, 1092-1094, 2014.

Le Quéré, C., Harrison, S. P., Prentice, I. C., Buitenhuis, E. T., Aumont, O., Bopp, L., Claustre, H., Cotrim Da Cunha, L., Geider, R., Giraud, X., Klaas, C., Kohfeld, K. E., Legendre, L., Manizza, M., Platt, T., Rivkin, R. B., Sathyendranath, S., Uitz, J., Watson, A. J., and Wolf-Gladrow, D.: Ecosystem dynamics based on plankton functional types for global ocean biogeochemistry models, Glob. Change Biol., 11, 2016-2040, 2005. 
Li, W. K. W.: Macroecological patterns of phytoplankton in the northwestern North Atlantic Ocean, Nature, 419, 154-157, 2002.

Litchman, E., Klausmeier, C. A., Miller, J. R., Schofield, O. M., and Falkowski, P. G.: Multi-nutrient, multi-group model of present and future oceanic phytoplankton communities, Biogeosciences, 3, 585-606, doi:10.5194/bg-3-585-2006, 2006.

Litchman, E., Klausmeier, C. A., Scholfield, O. M., and Falkowski, P. G.: The role of functional traits and trade-offs in structuring phytoplankton communities: scaling from cellular to ecosystem level, Ecol. Lett., 10, 1-12, 2007.

Litchman, E., Klausmeier, C. A., and Yoshiyama, K.: Contrasting size evolution in marine and freshwater diatoms, P. Natl. Acad. Sci. USA, 106, 2665-2670, 2009.

López-Urrutia, A., San Martin, E., Harris, R. P., and Irigoien, X.: Scaling the metabolic balance of the oceans, P. Natl. Acad. Sci. USA, 103, 8739-8744, 2006.

Marañón, E., Cermeño, P., Latasa, M., and Tadonléké, R. D.: Termperature, resources, and phytoplankton size structure in the ocean, Limnol. Oceanogr., 57, 1266-1278, 2012.

Marañón, E., Cermeño, P., López-Sandoval, D. C., RodríguezRamos, T., Sobrino, C., Huete-Ortega, M., Blanco, J. M., and Rodríguez, J.: Unimodal size scaling of phytoplankton growth and the size dependence of nutrient uptake and use, Ecol. Lett., 16, 371-379, 2013.
McCreary, J. P., Kohler, K. E., Hood, R. R., Smith, S., Kindle, J., Fischer, A. S., and Weller, R. A.: Influences of diurnal and intraseasonal forcing on mixed-layer and biological variability in the central Arabian Sea, J. Geophys. Res., 106, 7139-7155, 2001.

Partensky, F., Hess, W. R., and Vaulot, D.: Prochlorococcus, a marine photosynthetic prokaryote of global significance, Microbiol Mol. Biol. R., 63, 106-127, 1999.

Platt, T. and Denman, K.: Organisation in the pelagic ecosystem, Helgoländer Meeresunters 30, 575-581, 1977.

Rodríguez, J., Tintoré, J., Allen, J. T., Blanco, J. M., Gomis, D., Reul, A., Ruíz, J., Rodríguez, V., Echevarría, F., and JiménezGómez, F.: Mesoscale vertical motion and the size structure of phytoplankton in the ocean, Nature, 410, 360-363, 2001.

Sal, S. and López-Urrutia, Á.: Comment: Temperature, nutrients, and the size-scaling of phytoplankton growth in the sea, Limnol. Oceanogr., 56, 1952-1955, 2011.

Sommer, U.: A comparison of the Droop and the Monod models of nutrient limited growth applied to natural populations of phytoplankton, Funct. Ecol., 5, 535-544, 1991.

Sprules, W. G. and Munawar, M.: Plankton size spectra in relation to ecosystem productivity, size, and perturbation, Can. J. Fish. Aquat. Sci., 43, 1789-1794, 1986.

Tremblay, J.-E. and Legendre, L.: A model for the size-fractionated biomass and production of marine phytoplankton, Limnol. Oceanogr., 39, 2004-2014, 1994. 